CASE NOTE

\title{
RE DLSV AND MINISTER FOR IMMIGRATION AND BORDER PROTECTION [2017] AATA 2999 (27 NOVEMBER 2017)
}

\author{
KIM RUBENSTEIN $^{*}$ AND ELIZABETH HARRIS ${ }^{\dagger}$
}

\section{TABLE OF CONTENTS}

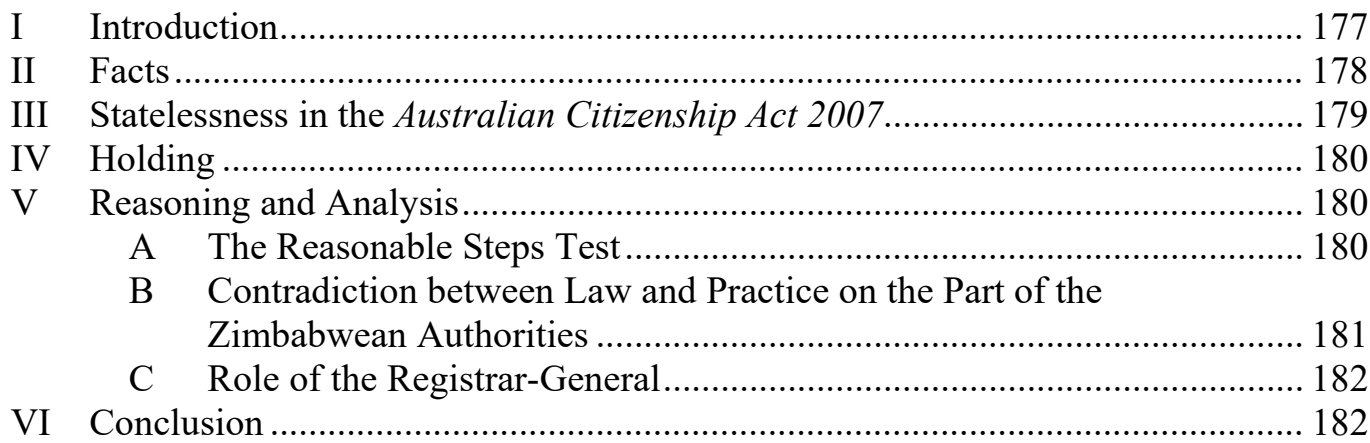

\section{INTRODUCTION}

This case note flows from a pro bono matter run by Professor Kim Rubenstein and students in her 2017 Australian National University administrative law class. ${ }^{1}$

Re DLSV and Minister for Immigration and Border Protection ('Re DLSV') 2 was an application for review to the Administrative Appeals Tribunal ('AAT') from a decision by the respondent denying the applicant's citizenship under s 21(8) of the Australian Citizenship Act 2007 (Cth) ('Act'). ${ }^{3}$

Born to Zimbabwean parents in Australia, the applicant was ineligible for Australian citizenship by birth alone because s 12 of the Act requires that at least one parent was an Australian citizen or permanent resident at the time the person was born, and this was not satisfied. ${ }^{4}$ The AAT was asked to determine whether

* Kim Rubenstein is a Professor in the Australian National University Law School and a Public Policy Fellow at the Australian National University. She can be contacted at kim.rubenstein@anu.edu.au.

$\dagger \quad$ Elizabeth Harris is a law student at the Australian National University. She can be contacted at elizabethpsrharris@gmail.com.

1 You can read more about this aspect of student involvement in the case in 'Monthly Bulletin' (Institute on Statelessness and Inclusion, January 2018) $<$ https://mailchi.mp/c8d0c908d1d4/statelessness-bulletin-january-1644161? e=63d4bfc24f $>$.

2 [2017] AATA 2999 (27 November 2017) ('Re DLSV').

3 The Australian Citizenship Act 2007 (Cth) provides in s 52 that decisions made under s 24 based on an applicant's eligibility under s 21(8) can be reviewed by the Administrative Appeals Tribunal ('AAT'). The AAT stands in the shoes of the original decision maker and has the power to make what it determines is the correct or preferable decision. See Administrative Appeals Tribunal Act 1975 (Cth) s 43(1); Re Drake and Minister for Immigration and Ethnic Affairs (No 2) (1979) 2 ALD 634.

$4 \operatorname{Re} \operatorname{DLSV}(\mathrm{n} 2)[7]-[8]$. 
the applicant, however, satisfied s 21(8) on the ground that she was born in Australia and would otherwise be stateless. ${ }^{5}$

The decision is important because of the distinction drawn between 'legal entitlement' to a foreign nationality or citizenship, ${ }^{6}$ and the practical entitlement to such status. In other words, in what circumstances can it be said that although a person might have an entitlement to foreign citizenship as a matter of law, the realities of how the foreign power treats applicants may be so obstructive as to make the right nugatory in fact?

\section{FACTS}

The applicant's father arrived in Australia in 2003 on a student visa. Her mother and brothers followed on a tourist visa in 2004. The applicant was born in Geelong, Victoria, in 2006 and was issued with an Australian birth certificate, ${ }^{7}$ but as her parents were neither Australian citizens nor permanent residents, she was ineligible for Australian citizenship. ${ }^{8}$

The applicant's parents did not register the applicant's birth with the Zimbabwean consulate in Australia. ${ }^{9}$ That registration would have allowed the applicant to acquire Zimbabwean citizenship by descent. ${ }^{10}$ The parents claimed their Zimbabwean passports were stolen and, without documentation, they thought the birth could not be registered. ${ }^{11}$ Furthermore, they were reluctant to bring the family's situation to the attention of the Zimbabwean authorities as they had applied for refugee status in Australia. ${ }^{12}$ Later they were compelled to leave Australia due to the poor health of the applicant's maternal grandfather, ${ }^{13}$ and withdrew that refugee application. ${ }^{14}$

After their return to Zimbabwe, the applicant's mother attended the Central Registry (the government office responsible for the issue of identity documents) on six occasions in an attempt to register the applicant's birth. ${ }^{15}$ She was told there was no way to do so except at the Canberra consulate. ${ }^{16}$ After advising to meet directly with the Registrar-General, which never eventuated, a staffer ultimately informed the applicant's family that there was no basis on which the applicant

$5 \quad \operatorname{Re} D L S V$ (n 2) [2]-[3]. Australian Citizenship Act 2007 (Cth) s 21(8) provides:

A person is eligible to become an Australian citizen if the Minister is satisfied that:

(a) the person was born in Australia; and

(b) the person:

(i) is not a national of any country; and

(ii) is not a citizen of any country; and

(c) the person has:

(i) never been a national of any country; and

(ii) never been a citizen of any country; and

(d) the person:

(i) is not entitled to acquire the nationality of a foreign country; and

(ii) is not entitled to acquire the citizenship of a foreign country.

$6 \operatorname{Re} D L S V$ (n 2) [48] (emphasis in original).

7 ibid [6].

$8 \quad \operatorname{Re} D L S V$ (n 2) [7]-[8]. See Australian Citizenship Act 2007 (Cth) s 12.

$9 \operatorname{Re} \operatorname{DLSV}(\mathrm{n} 2)[9]$.

10 ibid.

11 ibid [9], [15].

12 ibid [10].

13 ibid [16].

14 ibid [17].

15 ibid [18].

16 ibid [19]. 
could apply for citizenship. ${ }^{17}$ The Registry issued the applicant's parents with 'old-style' passports that had space for the names of children to be inscribed. ${ }^{18}$ However, the Registry refused to enter the names of the children with an official stamp, so the applicant's parents inscribed their children's names themselves. ${ }^{19}$

With their situation in Zimbabwe unsafe, the family left for South Africa in 2008. ${ }^{20}$ The applicant's mother continued to attend the Zimbabwean consulate in Johannesburg in an attempt to register the birth. ${ }^{21}$ These attempts were rebuffed on the basis that, without new-style passports, they did not have sufficient proof of identification. ${ }^{22}$

Effectively trapped in South Africa, the applicant's mother explained how they were subjected to harassment and the children were vulnerable to trafficking without their own identity papers. ${ }^{23}$

\section{STATELESSNESS IN THE AUSTRALIAN CITIZENSHIP ACT 2007}

As the decision maker in the AAT noted, Rubenstein had

explained the provisions of the Act were carefully crafted to give effect to Australia's treaty obligations in relation to stateless persons ... [therefore] at least in the context of stateless persons, Australian citizenship was not a privilege but could be a right. ${ }^{24}$

Critical to the determination of the principal issue was the disjunct between the applicant's theoretical and substantive eligibility for Zimbabwean citizenship: was the practical impossibility of the applicant registering her birth in Australia (which would have otherwise enabled her to obtain Zimbabwean citizenship) sufficient to render her unable to acquire Zimbabwean citizenship, and satisfy s 21(8)(d)?

Section 37 of the Constitution of Zimbabwe provides that persons born abroad are citizens by descent if either of their parents or any of their grandparents was a Zimbabwean citizen and the 'birth is registered in Zimbabwe in accordance with the law relating to the registration of births'. ${ }^{25}$

The applicant argued that the requirement that the birth be registered in accordance with the law' 26 rendered the procedural step of birth registration a substantive requirement of s $37 .{ }^{27}$ Therefore, if registration was not procedurally possible (as in this case), s 37 could not be satisfied and the applicant would be ineligible for citizenship. ${ }^{28}$ The applicant also argued that even if that interpretation was not accepted by the AAT, the facts showed the Zimbabwean government had refused the applicant's citizenship application and therefore, as a

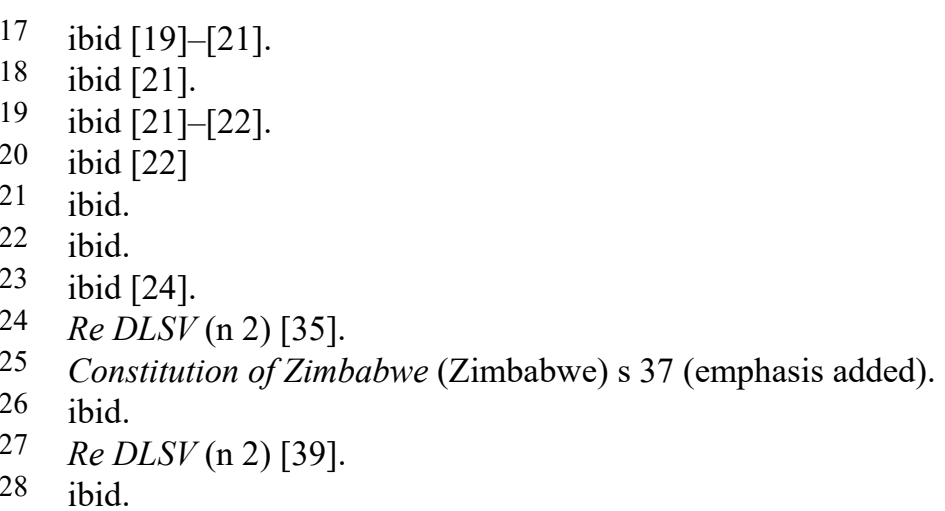


matter of practice, she was ineligible for Zimbabwean citizenship, satisfying $\mathrm{s}$ $21(8) .29$

\section{HOLDING}

AAT Deputy President Bernard J McCabe determined the applicant was not entitled to acquire Zimbabwean citizenship and was entitled to obtain Australian citizenship under s 21(8). ${ }^{30}$

The decision may be distilled down to the fact that although the applicant may have theoretically been eligible to obtain Zimbabwean citizenship, the administrative practices of the Zimbabwean government made this actually impossible. ${ }^{31}$

Deputy President McCabe also held that, even if there were failures on the part of the applicant's mother to pursue all avenues towards registering the applicant's birth with the Zimbabwean authorities, the practical obstacles that had been placed in her path led him to conclude that she had done all that she reasonably could. ${ }^{32}$ Taking the applicant as she was in her current circumstances, ${ }^{33}$ and to prevent her exploitation as a stateless minor, ${ }^{34}$ he determined that any failings on the part of the applicant's mother should not disentitle the applicant to citizenship under $\mathrm{s}$ 21(8). ${ }^{35}$

\section{REASONING AND ANALYSIS}

\section{A The Reasonable Steps Test}

The AAT endorsed the decision in Re KKRG and Minister for Immigration and Border Protection ('Re $K K R G$ ') $)^{36}$ in holding that there may be matters in which the practical obstacles to obtaining citizenship "effectively put citizenship out of reach', ${ }^{37}$ with the effect that the applicant 'is "not entitled to acquire" citizenship in the sense intended by the Act notwithstanding the existence of a formal legal right'. ${ }^{38}$ In Re AP and Minister for Immigration and Border Protection ('Re $\left.A P^{\prime}\right),{ }^{39}$ Senior Member PW Taylor SC noted that Australian citizenship should not be refused where there was 'irrefutable evidence that the person had no prospect of satisfying the procedural and administrative citizenship application requirements of the relevant foreign country'. 40

The AAT in $R e D L S V$ applied the test in $\operatorname{Re} K K R G$ to the effect that 'a person is not genuinely entitled to acquire the citizenship of another country if the application requirements "are so onerous as to undermine or negate the

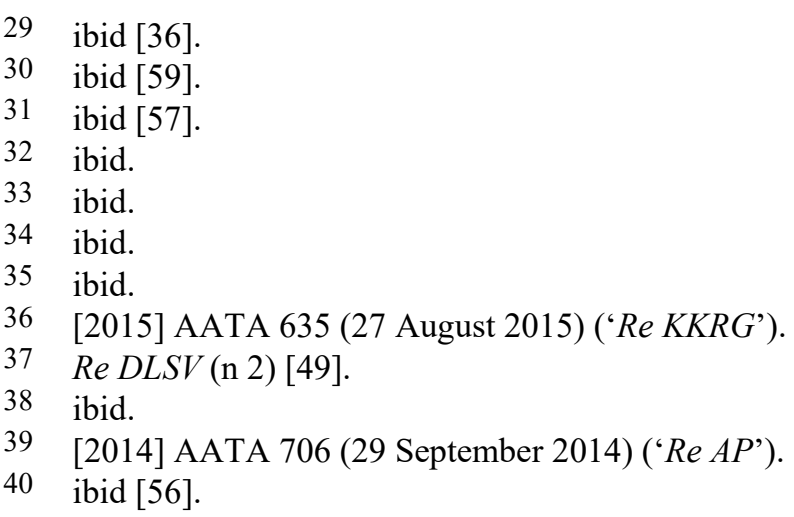


'underlying eligibility or qualification"', ${ }^{41}$ In so doing, the AAT rejected the argument of the respondent that the reasonable steps test had not been satisfied because the applicant's parents had failed to register the birth at the Zimbabwean embassy in Canberra. ${ }^{42}$

The AAT accepted the argument of the applicant that the failure of her parents 'should not be held against the applicant', 43 and that the question was 'what can legally and practically be done now'. ${ }^{44}$ Accepting the testimony of the applicant's mother with regard to the actions of the Registrar-General in refusing to register the birth, the AAT held that even if the family's failure to register the birth in Canberra was born out of a desire to obtain Australian citizenship, 'events appear to have overtaken them' 45 and it was factually clear that the practical obstacles to obtaining citizenship were such that in reality, the applicant was not entitled to registration. 46

\section{B Contradiction between Law and Practice on the Part of the Zimbabwean}

\section{Authorities}

As outlined above, the applicant's parents faced several procedural obstacles in attempting to register her birth.

This was of particular importance to the AAT's decision. Section 37 of the Constitution of Zimbabwe required that prior to an application for citizenship by descent being made, the birth had to be registered 'in accordance with the law relating to the registration of births' ${ }^{47}$ The Zimbabwean authorities (the Office of the Registrar-General, and various Zimbabwean consulates) provided conflicting information to the applicant regarding the manner in which a birth registration was to be done. ${ }^{48}$ However, discretion to award citizenship is ultimately vested in the Registrar-General, and the AAT took note of his unwillingness to register the birth even when the applicant's parents presented themselves in Harare. ${ }^{49}$

The obstacles faced by the applicant evinced not only a contradiction between law and practice, but also a lack of consistent policy to guide practice, in order to fulfil legal requirements. These practical irregularities led to procedural barriers that the applicant was unable to break through.

It was not only bureaucratic inefficiencies that affected the (im)possibility of obtaining citizenship. While the Deputy President acknowledged the Department of Foreign Affairs and Trade's advice that, in the case of Zimbabwe, it was only high-profile émigrés who were likely to face a serious risk of harassment, he held that this did not exclude the possibility of 'low level harassment and administrative intransigence' being applied. ${ }^{50}$ The oppressive nature of a regime may render

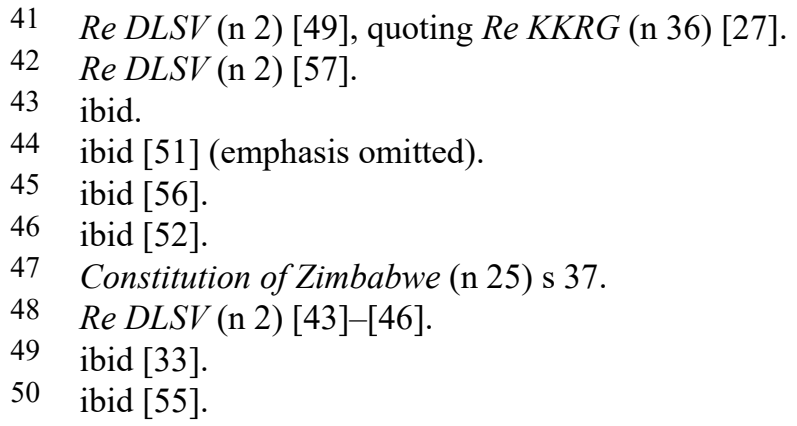


approaching the government to make an application unpalatable (or even dangerous) to a risk-averse applicant. ${ }^{51}$

The AAT did not discuss in detail the effect of the applicant's mother's testimony concerning her treatment at the hands of the authorities, so it remains to be seen whether, in conditions of practical openness to applications, the oppressive nature of a government more generally can affect the 'reasonable steps' test.

\section{Role of the Registrar-General}

The Registrar-General had the power to register the births of persons overseas and provide them with a birth certificate under s 5(2) of the Births and Deaths Registration (General) Regulations 1988.52

The respondent argued that registration through the Canberra embassy should have been attempted again. ${ }^{53}$ The AAT did not require the applicant to attempt this course of action, ${ }^{54}$ and accepted the applicant's mother's assertion that the Registrar-General's previous attitude indicated that 'the application would be lost in the labyrinth of the Central Registry office'. ${ }^{55}$

The Registrar-General's actions, being in contradiction with the implied procedural requirements of $\mathrm{s} 37,{ }^{56}$ rendered it impossible for the applicant to register her birth.

This indicates that an applicant will not be required to repeatedly attempt to comply with foreign citizenship requirements when the relevant administration consistently renders such attempts futile.

\section{CONCLUSION}

Deputy President McCabe confined this decision to its 'unusual circumstances', ${ }^{57}$ and noted the time pressures acting on him with the applicant being in a particularly vulnerable position as a stateless person residing in South Africa. ${ }^{58}$

The applicant has since been issued with an Australian passport and the remaining family members are now seeking to regularise their Zimbabwean passports. Given this was an AAT — and not a Federal Court — decision, it is unclear whether the respondent will treat this decision as one specific to its own facts or be guided by it as a general approach to the application of s 21(8).

The decision in $R e D L S V$ reinforces the approach taken in $\operatorname{Re} K K R G$ and $\operatorname{Re} A P$ that obstructionist behaviour by foreign governments will not adversely affect $\mathrm{s}$ 21(8) applicants, so long as these applicants have taken reasonable steps to acquire a foreign citizenship. This means consideration must be given not only to the steps taken to fulfil the requirements set out by foreign governments, but also to the

51 See Human Rights Watch, World Report (Report, 2019) 671-74; Jason Burke, 'Zimbabwe Crackdown Could Last Months, Activists Fear' The Guardian (Harare, 27 January 2019) $<$ www.theguardian.com/world/2019/jan/27/zimbabwe-crackdown-will-continue-forforseeable-future-activists-fear $>$.

52 (Zimbabwe); Re DLSV (n 2) [28].

$53 \operatorname{Re} D L S V$ (n 2) [27].

54 ibid [52].

55 ibid [34].

56 ibid [39].

57 ibid [57].

58 ibid. 


\section{Case Note}

practical circumstances in which applicants find themselves as a result of the conduct of those governments. 